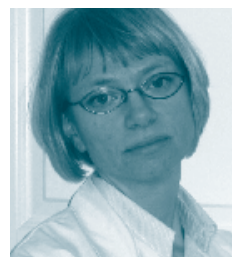

Torunn Hatlen Nøst, sykepleier, MSC, sykepleiefaglig rådgiver Kirurgisk klinikk,

St. Olavs Hospital www.sykepleien.no

Les mer og finn litteraturhenvisninger på våre nettsider.

\section{Søkeord:} ) Dokumentasjon - Observasjon

) Sykepleier-pasientforhold , Hermeneutikk

\title{
VIPS må romme pasientens fortelling
}

Språket i sykepleiedokumentasjonen ivaretar ikke pasientperspektivet.

D okumentasjon av sykepleie har i flere år og studier blitt kritisert både for innhold, språk og manglende pasientperspektiv $(1,2,3)$. Sykepleiere etterlyser muligheten til å registrere data om den menneskelige omsorgen i sykepleiedokumentasjon og opplever dataspråket som fremmedgjørende $(4,5)$. Mange savner et pasientperspektiv i sykepleiedokumentasjonen $(6,7,8,9)$. Med det menes en synliggjøring av individualisert pasientomsorg med rom for den enkelte pasientens erfaringer og opplevelser (6,7). Sykepleiedokumentasjonen ivaretar ikke et slikt pasientperspektiv til tross for at man er enig om at det er vesentlig for både sykepleiedokumentasjonen og utøvelse av sykepleie $(9,10)$.

\section{Språket}

Innføring av dokumentasjonsmodellen VIPS var utgangspunktet for min masteroppgave i helsevitenskap. Hensikten med studien var å belyse og drøfte hvordan bruk av modeller kan prege samhandling med andre. Er det slik at ved å innføre en modell for sykepleiedokumentasjon med det språket den innebærer, så vil det etterlyste pasientperspektivet være på plass?

Språket innen sykepleie har de siste 150 årene utviklet seg fra å være medisinsk preget til å bli et humanistisk språk (3). Kritikken mot sykepleiedokumentasjonen kan ses i lys av denne utviklingen. Samtidig har det vært et ønske om at fagspråket i sykepleie skal springe ut fra praksis. Det skulle føre til beskrivende begreper med rot i den kliniske sykepleien (3). Ved innføring av EPJ og overgangen til en elektronisk sykepleiedokumentasjon, ønsket man et standardisert og formalisert språk (11). Det skulle bidra til bedre kommunikasjon om og forståelse av pasientens helseproblem. I dette ligger det en prinsipiell utfordring: Hva i språket kan standardiseres, og hva er det man kan dokumentere i pasientens fortelling med et standardisert språk?

\section{Metode}

Undersøkelsen ble gjort i en somatisk klinikk ved et universitetssykehus. Jeg valgte en kvalitativ forskningstilnærming der jeg observerte innkomstsamtale mellom sykepleier og pasient.
Feltet ble avgrenset til å gjelde elektive innleggelser uavhengig av diagnose, alder og kjønn. Sammenhengen mellom VIPS og innkomstsamtalen er fasene sykepleieanamnese og pasientstatus (12).

I samtalen forteller pasienten om hvordan han har det. Han bruker er subjektivt språk med beskrivelser av hvordan sykdommen arter seg i hverdagen og hvordan livet med sykdommen er. Pasienten bruker sitt språk for å fortelle om og dele sine opplevelser. I innkomstsamtalen tar sykepleieren del i pasientens fortelling og gir tilbakemelding på det han forteller om sykdommen og sin livssituasjon ved å nikke, bruke uttrykk som «mmm», «jeg forstår» og lignende.

\section{Nøktern beskrivelse}

Språket i sykepleiedokumentasjonen er nøytralt, og innholdet gir teksten et mekanisk og oppramsende preg. Språket gir inntrykk av et subjekt-objektforhold hvor sykepleieren betrakter det pasienten har fortalt på avstand. Språket er preget av medisinske begreper

\section{Språket i sykepleiedokumen- tasjonen er nøytralt.}

og terminologi. Det er et vitenskapelig språk i denne delen av teksten og ikke nødvendigvis det samme språket som pasienten bruker. I friteksten som kan gjengi pasientens erfaringer med hans ord, fant jeg et språk som er beskrivende på en nøktern måte. Begreper for å beskrive følelser, verdier, opplevelser og erfaringer er vanskelig å få øye på.

Kartlegging av pasienten dokumenteres i journalen på en slik måte at alle som samarbeider om pasienten vet hvordan for eksempel boforholdene hans er. Kartleggingen sier ingenting om hva han tenker rundt det å skulle reise hjem. Heller ikke om hvilke tanker som ligger bak tilrettelegging i hjemmet eller bruk av hjelpemidler. Kartleggingen består av en nøktern beskrivelse av hva som er objektive fakta; fakta som er etterprøvbare og entydige. Det er de fysiske hjelpemidlene og fasilitetene rundt 
pasienten som kartlegges og ikke hans ressurser, evner eller vurderinger. Det kan se ut som pasientens historie settes til side av sykepleieren og EPJ når fortellingen skal inn i det formatet VIPS og innkomstnotatet har.

\section{Konflikt}

Sykepleier og pasient møtes til innkomstsamtalen med til dels ulike hensikter. Sykepleieren vil kartlegge pasienten og informere om det som skal skje i forbindelse med sykehusinnleggelsen, mens pasienten i tillegg til å få informasjon om hva som skal skje, vil dele sine opplevelser. Her kan det se ut som om det er en konflikt mellom det pasienten opplever og erfarer

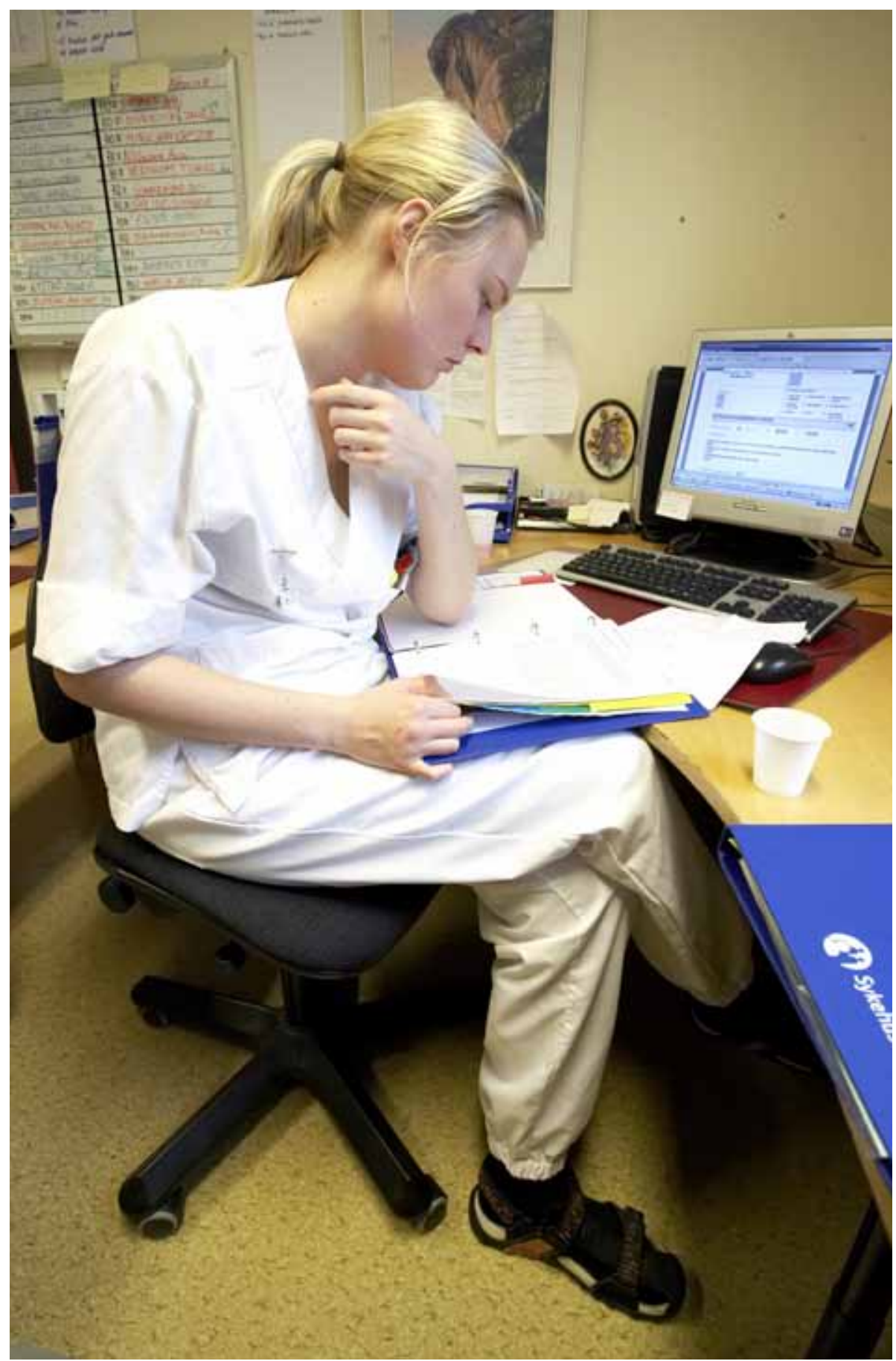

DIALOG: Pasientens fortelling og opplevelser må få rom både i møtet mellom pasient og sykepleier og i sykepleiedokumentasjonen. Arkivfoto Erik M. Sundt med sin sykdom, og sykepleierens agenda. På bakgrunn av dette datamaterialet kan det være vanskelig å slå fast hvilken rolle dokumentasjonsmodellen spiller i denne konflikten. Men det kommer frem at det er sykepleieren som styrer samtalen med utgangspunkt i hva hun vil ha fylt ut i forhold til søkeordene i VIPS.

\section{Pasientperspektiv}

Hvis vi ser på det som beskrives som formålet med sykepleieanamnese og pasientstatus i VIPS, er det ikke så galt om det er et mål å ta opp de temaer modellen viser til gjennom søkeordene. I VIPS er det en uttrykt hensikt at det er den aktuelle pasientens behov for sykepleie som skal kartlegges og dokumenteres (12). Likevel er det vanskelig å få øye på pasientens individuelle fortelling i innkomstnotatene. Da kan det være det er perspektivet og innholdet som blir grepet og løftet frem som gjør innkomstnotatet lite pasientrettet. Det er de medisinske opplysningene som blir dominerende, og det er svært tydelig gjennom den medisinske diagnosens plass i kontaktårsak og helsehistorie. En slik forskyvning av modellens hensikt i møte med praksis kan være det som gjør at sykepleiedokumentasjonen ikke viser til et pasientperspektiv, og ikke nødvendigvis modellen i seg selv. Ifølge Grimen (13) kan en humanistisk kultur ikke utelukkes fra helsefagene, slik den heller ikke kan det fra medisinen. Det vil i så fall føre til at vi mister de beste tilgjengelige forklaringene på fenomenene som helsearbeidere møter i praksis. Og uten de beste tilgjengelige forklaringene kan vi heller ikke forstå pasienten, og da vil det være naturlig å trekke den konklusjon at vi heller ikke kan hjelpe ham på den beste mulige måten. Det er et argument som taler for at sykepleiedokumentasjon bør inkludere en humanistisk forståelse av sykdom for å kunne få frem et pasientperspektiv.

\section{Viktig debatt}

Forbedringer i sykepleiedokumentasjonen omtales ofte i sammenheng med kvalitet og kvalitetssikring. Det innebærer å sikre at pasientens syn blir en del av kvalitetsprosessen (8) og kan ses i sammenheng med pasientperspektivet. Dahl \& Vatne (6) har satt søkelyset på de ulike perspektiver som kommer frem i sykepleiedokumentasjonen. De inviterer til en viktig debatt når de spør om vi ved å være opptatt av å legitimere faget sykepleie, har mistet interessen for hva pasienten er opptatt av? Funnene i denne studien støtter opp under påstandene om et manglende pasientperspektiv i sykepleiedokumentasjonen. Det reiser spørsmålet om en legitimering av faget sykepleie innebærer en tilnærming til en medisinsk forståelse og kultur.

Bevissthet og refleksjon rundt egen dokumentasjonspraksis kan føre til en bedre tilpasning av VIPS-modellen til praksis. Utøvere i praksisfeltet må bli mer bevisst modellens intensjoner og hvordan de selv bruker den. For å få tak i pasientens fortelling og pasientperspektivet, må sykepleieren være bevisst på hva man vil og hva man søker å forstå gjennom innkomstsamtalen. Når sykepleieren under innkomstsamtalen innleder med at «vi bruker å spørre om det her» eller «skal vi se her» og viser til malen i sykepleiedokumentasjonen, er det ikke sikkert at det fremmer pasientperspektivet i samtalen eller i sykepleiedokumentasjonen.

\section{Veiskille}

Kärkkäinen, Bondas og Eriksson (9) viser til at sykepleiedokumentasjonen er kommet til et veiskille og at det er uvisst hvilken retning utviklingen vil ta. De fremhever at sykepleiedokumen- 
tasjonen må få plass som en viktig del av pasientomsorgen. At pasientens perspektiv blir en del av sykepleiedokumentasjonen er en forutsetning for god sykepleiedokumentasjon. Det kan gjøres ved at pasienten får anledning til å uttrykke seg fritt, noe som gir assosiasjoner til å finne rom til pasientens fortelling $i$ sykepleiedokumentasjonen. Kanskje skillet mellom samtalen og teksten kan indikere at sykepleiedokumentasjonen, og arbeidsprosessene knyttet til den, ikke betraktes som en del av pasientomsorgen og det kliniske arbeidet? Det kan ses på som et eksempel på gap mellom teori og praksis der det må bygges bro for at oppgavene skal integreres i hverandre. Og da er vi tilbake til språket som kan være brobygger, men som i EPJ synes å være prisgitt de rammene vi gir den.

Ifølge Fiskum (7) kan vitenskapens språk bli for avgrensende når en sykepleier skal formidle det relasjonelle, og derfor bør sykepleiere inkludere pasientens opplevelse og forståelse av sin egen situasjon. Dette språket kan vi finne i fortellingen til pasienten. Det handler ikke bare om strukturen i et dokumentasjonssystem, det handler om hvilke verdier man vil vektlegge og hvilken identitet sykepleie skal ha. Det er rom for en humanistisk forståelse av sykdom når sykepleiedokumentasjonen struktureres etter VIPS-modellen, men det er opp til praksis å åpne opp for et slikt rom og etterspørre slik kunnskap om pasienten.

\section{Overførbarhet}

Observasjon som metode har gitt informasjon om hva som skjer under innkomstsamtalen og hvilken mening som kommer frem der. Tilnærmingen til feltet har gitt data som har vært informative slik at relevansen til metoden som er brukt, vurderes som tilfredsstillende. Validitet peker på hva man har funnet ut noe om, og hvilken overførbarhet funnene har. Innkomstsamtalen var en god arena for å få frem ulike typer data, og funnene kan være overførbare til andre deler av sykepleiedokumentasjonen og VIPS. Men man kan stille spørsmål ved om fem observasjonssituasjoner er tilstrekkelig til at funnene kan være overførbare. Malterud (14) viser til at et høyt antall informanter ikke nødvendigvis er kriterier for et overførbart resultat. Kvale (15) peker på en kommunikativ validitet som innebærer forskerens evne til å kommunisere forskningen sin på en forståelig måte. De prinsipielle spørsmål som kommer frem på bakgrunn av undersøkelsen, er uansett av verdi og viser at man har funnet interessante svar på problemstillingen. Det er behov for mer kunnskap om hvordan en modell virker inn på møtet mellom pasient og sykepleier og hva vi kan gjøre for å få et mer fremtredende pasientperspektiv i dokumentasjon av sykepleie.

Refleksivitet er nødvendig i hele forskningsprosessen og spørsmålet er ikke om forskeren påvirker prosessen, men hvordan. I møte med forskningsfeltet var det viktig å sette skepsisen i forforståelsen til side slik at det som kom frem under feltarbeid og observasjon skulle få rom i den nye forståelsen. Det har vært tilstrebet under hele arbeidet, selv om man må erkjenne at tilstedeværelsen man har som observatør vil prege informantene.

\section{Konklusjon}

En del av kritikken mot papirbasert sykepleiedokumentasjon viste til at det var lite faglig uttrykk i den, den var dagbokpreget og pasientens behov for sykepleie kom i liten grad frem. Det var noe av bakgrunnen for utviklingen av den elektroniske sykepleiedokumentasjonen, og det var store forventninger til gevinstene EPJ skulle avstedkomme. Undersøkelsen har ikke avdekket noen endring ved overføring til EPJ. Det standardiserte språket sees kun gjennom VIPS-modellens søkeord, og pasientperspektivet er fremdeles fraværende.

\section{Sykepleier og pasient møtes til innkomst- samtalen med til dels ulike hensikter.}

I innkomstsamtalen er det tendenser til en treleddet relasjon, slik Skjervheim (16) beskriver det, og et pasientperspektiv. Men agendaen fra dokumentasjonssystemet kan også påvirke strukturen for møtet mellom pasient og sykepleier dersom ikke sykepleieren tilstreber en åpen tilnærming til samtalen, pasienten og hans fortelling. I oversettelsen mellom tekst og tale kan det skje en forskyvning av meningen i pasientens fortelling til tekstens format. For å få tak i pasientens fortelling er derfor dialogen sentral og må få rom både i møtet mellom pasient og sykepleier og i sykepleiedokumentasjonen. Dette vil bidra til at den humanistiske tilnærmingen til sykdom og helse i sykepleien opprettholdes også i dokumentasjonen av den. Og pasientens fortelling og pasientperspektivet vil få sin plass i sykepleiedokumentasjonen. IIII 